\title{
Macroeconomic Implications for Hong Kong SAR of Accommodative U.S. Monetary Policy
}

\author{
Papa N'Diaye
}




\title{
IMF Working Paper
}

Asia and Pacific Department

\section{Macroeconomic Implications for Hong Kong SAR of Accommodative U.S. Monetary Policy}

Prepared by Papa N'Diaye

Authorized for distribution by Nigel Chalk

November 2009

\begin{abstract}
This Working Paper should not be reported as representing the views of the IMF. The views expressed in this Working Paper are those of the author(s) and do not necessarily represent those of the IMF or IMF policy. Working Papers describe research in progress by the author(s) and are published to elicit comments and to further debate.

This paper discusses the potential macroeconomic implications for Hong Kong SAR of accommodative monetary policy in the United States. It shows, through model simulations, that a resumption of the credit channel in Hong Kong SAR has the potential to create inflation in both goods and asset markets. Expansionary financial conditions will likely have a greater impact in fueling asset price inflation, manifested in the model through a strong increase in equity prices. Higher asset prices could, in turn, through a financial accelerator mechanism, lead to further credit expansion and an upward cycle of asset prices and credit. This cycle, if unchecked, can potentially feed into volatility in consumption, output and employment and complicate macroeconomic management. The simulation results suggest there is a role for countercyclical prudential regulations to mitigate the amplitude of the cycle and lessen the financial and macroeconomic volatility associated with an unwinding of the credit-asset price cycle.
\end{abstract}

JEL Classification Numbers: E51, E58, E37, H50.

Keywords: Monetary policy, financial accelerator, asset prices, GIMF.

Author’s E-Mail Address: pndiaye@imf.org 


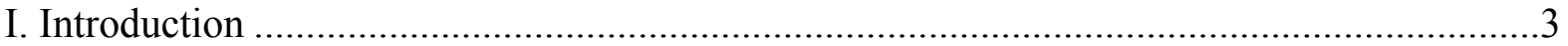

II. Implications for Hong Kong SAR of U.S. Monetary Policy …...................................4

A. The Fed's Unconventional Monetary Policy Actions...........................................4

B. Impact on Hong Kong SAR ...................................................................................

III. A Simulation of Hong Kong SAR Asset and Goods Markets When Confronted by an

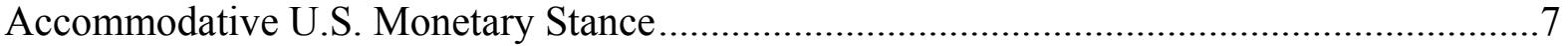

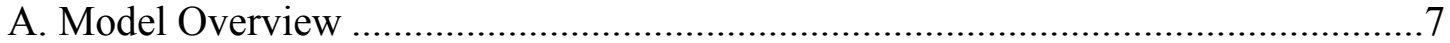

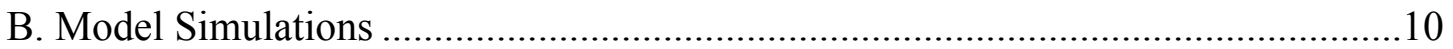

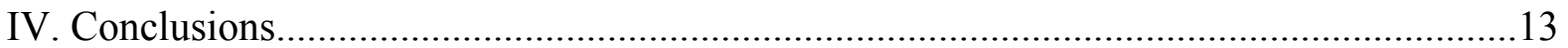

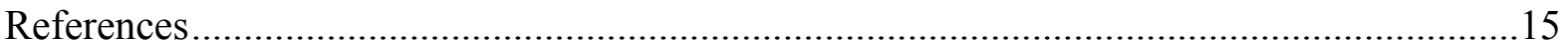




\section{INTRODUCTION}

In an effort to counter the fallout of the global financial crisis, central banks in major economies, particularly the U.S Federal Reserve, have lowered their policy rates to near zero and introduced a set of measures aimed at increasing liquidity and stimulating credit. These measures included serving as lender of last resort for systemically important institutions, creating new central banks facilities to inject liquidity, and buying government or corporate securities. ${ }^{1}$ For Hong Kong SAR, the linked exchange rate system (LERS) implies that the Fed's monetary policy stance is imported directly into the Hong Kong economy and this has helped, alongside other measures taken by the government, the Hong Kong economy to weather the effects of the global financial crisis. Now that the Hong Kong economy is recovering, however, there is a potential for the imported accommodative monetary policy stance to create inflation in assets and goods markets. In particular, asset price increases have the potential, through a financial accelerator process, to raise the availability of collateral for borrowing, which can fuel the demand for credit, and potentially create an asset prices-credit cycle.

Against this backdrop, this paper discusses the potential implications for Hong Kong SAR of the maintenance of accommodative monetary policy in the United States alongside an improvement in the Hong Kong and Mainland economies. It presents briefly the measures that have been taken by the United States and draws out their impact to date on Hong Kong's economy. Second, the paper performs simulations, using a version of Global Integrated Monetary and Fiscal Model that includes a financial accelerator channel, to examine quantitatively the potential impact such a combination of factors could have on the Hong Kong economy. The last section concludes the paper.

The main conclusions are:

- A resumption of the credit channel in Hong Kong SAR and a turnaround in the money multiplier, has the potential to create inflation in both goods and asset markets.

- $\quad$ Such expansionary financial conditions will have a greater impact in fueling asset price inflation, manifested in the model through a strong increase in equity prices.

- $\quad$ Higher asset prices could, through a financial accelerator mechanism, in turn increase credit expansion and fuel an asset price-credit boom cycle.

- $\quad$ Consumer price inflation will likely pick up but slower and to a much lesser extent since it will take time to unwind excess capacity in goods markets.

\footnotetext{
${ }^{1}$ See October 2009 GFSR for a discussion of the measures undertaken by central banks and their impact on markets.
} 
- $\quad$ Fiscal policy could be used to restrain asset price increases but doing so will likely have a large impact on the real economy. As such, countercyclical prudential regulations may be a more appropriate tool to tackle such a credit-asset price cycle.

\section{ImPlications For Hong Kong SAR OF U.S. Monetary Policy}

\section{A. The Fed's Unconventional Monetary Policy Actions}

In response to the global financial crisis, the Fed lowered interest rates to near zero to ease monetary conditions. The federal funds rate (FFR) was lowered from $5 \frac{1}{4}$ percent to 0.16 percent between June 2007 and August 2009. However, high levels of risk aversion have prevented this large reduction of the FFR to translate into lower market rates.

The apparent breakdown in the monetary transmission mechanism in the U.S. prompted the Fed to take more dramatic steps aimed at tilting down the yield curve and stimulating credit creation. Such measures included 1) creating new central bank facilities as well as loosening the terms and availability of existing facilities; 2) expanding the central bank's balance sheets through purchases of government, government-guaranteed, or corporate securities from banks or other institutions; 3) alleviating financial distress in particular
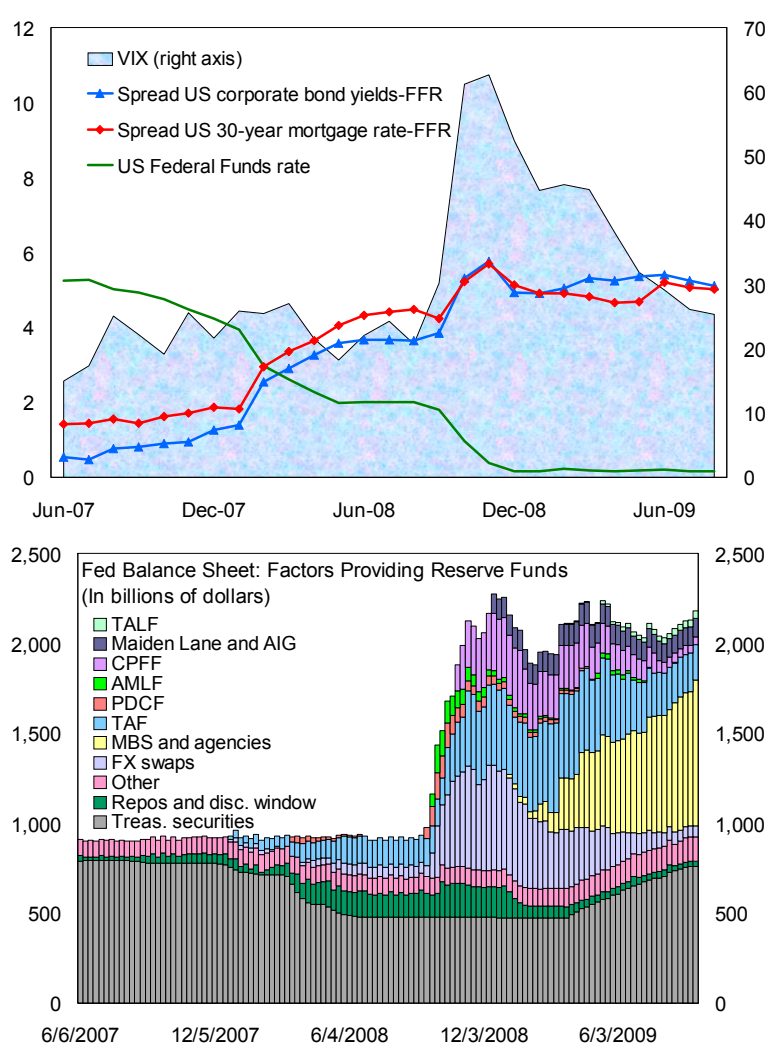
credit markets that are deemed to play a key role in supporting economic activity; and 4) improving communication. In particular:

1. Creating new central bank facilities to respond to demand from specific credit markets. Four facilities were introduced to reduce stress in debt markets through either direct government purchases or the provision of liquidity to allow financial institutions to purchase particular instruments. These were the Asset-Backed Commercial Paper Money Market Mutual Fund Liquidity Facility (AMLF), Commercial Paper Funding Facility (CPFF), the Money Market Investor Funding Facility (MMIFF) and the Term Asset-Backed Securities Loan Facility (TALF).

2. Purchasing government or corporate securities to reduce rates on longer maturity government instruments. In November, 2008 the Federal Reserve announced plans to purchase agency debt and by December the FOMC statement indicated the Fed would also begin purchasing long-term Treasuries. By September 2009, the Fed was holding US $\$ 810$ billion in agency debt and MBS and around US\$760 billion in treasury securities. 
3. Alleviating financial distress by expanding the scope of central bank liquidity provision. In addition to the usual windows available to depository institutions, the Federal Reserve has introduced the Term Auction Facility (TAF) to provide collateralized term funds to depository institutions, as well as the Term Securities Lending Facility and Primary Dealer Credit Facility (PDCF) to provide overnight and term funding to primary dealers. The Fed has also provided U.S. dollar liquidity internationally through foreign currency swaps with other central banks.

4. Improving communications. The Fed has committed to maintain an accommodative stance of monetary policy for a sustained period. FOMC statements have explicitly noted that exceptionally low rates will be warranted for some time.

\section{B. Impact on Hong Kong SAR}

With the linked exchange rate system, Hong Kong SAR has imported the extraordinary measures taken by the Fed. In particular, Hong Kong's base interest rates have been lowered to $1 / 2$ percentage points (from $63 / 4$ percent in mid 2007) alongside the reductions in the fed funds rate.

At the same time, large capital inflows, in part attracted to equity and property markets but also drawn in by the stability in the banking system and the government credible deposit guarantee, has led the HKMA to intervene as the Hong Kong dollar hit the strong side of the convertibility undertaking. The HKMA has purchased U.S. dollars and sold Hong Kong dollars resulting in a more-thandoubling of the monetary base (which reached HK $\$ 804$ billion by end September 2009).

At the same time, demand for high quality and liquid instruments has driven the yields on exchange fund papers close to zero even up to 12 months maturities. The excess demand for exchange fund papers prompted the HKMA to increase its issuance of exchange fund bills, shifting funds from the aggregate balance to the exchange fund papers (both of which are part of the monetary base).
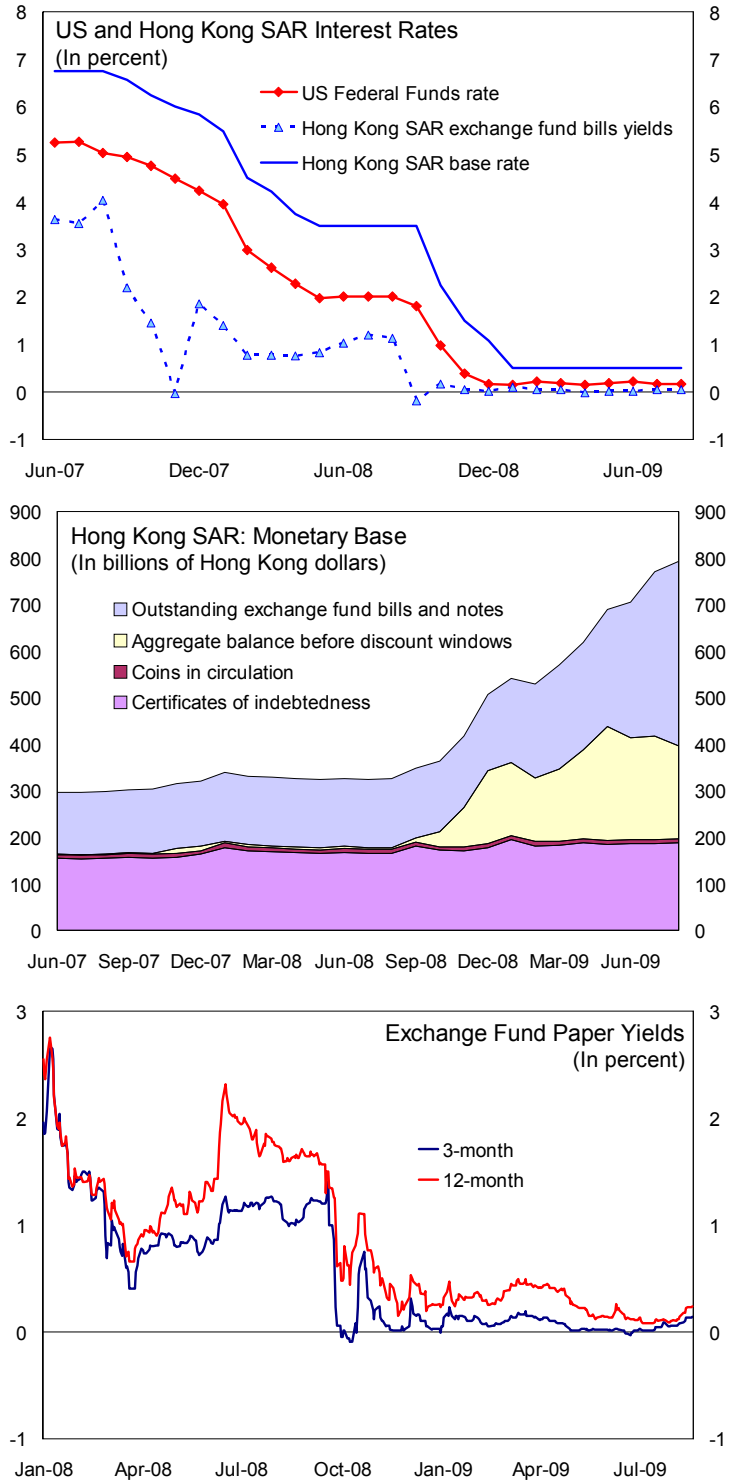
However, there are signs that the monetary transmission mechanism in Hong Kong has been affected by the recent global financial crisis. The rise in the monetary base has not been accompanied by an increase in credit. Instead, the money multiplier has fallen as banks have become more cautious about new lending and uncertainties about the recovery have restrained the demand for credit. However, with the money multiplier now around half where it was before the collapse of Lehman, the large increase in Hong Kong dollar liquidity could translate into rapid credit growth should the monetary transmission mechanism re-establish itself.

Despite the sluggishness in the growth of total credit, there are now signs of a burgeoning recovery in credit to particular sectors, notably real estate. Also, equity markets prices have rebounded. The rise in equity prices seems to be related in part to the strength of activity in the Mainland, which has helped support the Hong Kong economy. Other factors, such as the relatively low interest rates in major economies and declining global risk aversion, may have also caused resurgence in the global search for yields. As a result, liquidity has flowed into a range of asset markets, including in Asia. For Hong Kong SAR, balance of payment data for the first half of this year shows a rebound in nonresident net equity holdings (although interpreting this evidence is not straightforward since the data are reported on a net basis).

In the coming months, higher asset prices have the potential to feed through to private consumption through wealth effects and provide further support to demand. In addition,
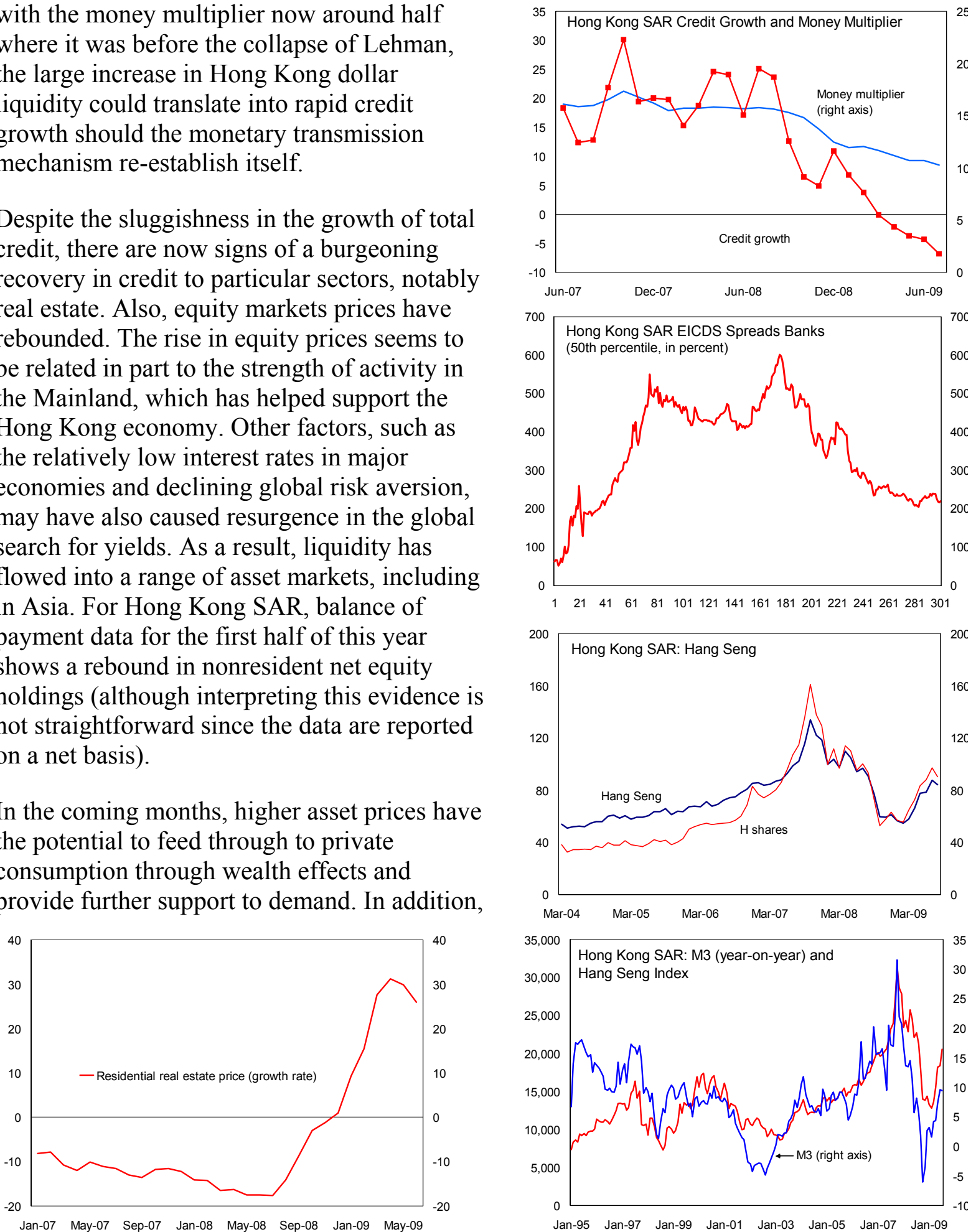
higher asset prices has the potential to raise the value of the eligible asset collateral for borrowers, and lower the "external finance premium" (i.e. the credit risk associated with borrowing from financial markets - relative to the cost of using retained earnings - that is a result of uncertainty and information asymmetries). By posting a higher level of collateral borrowers can reduce their costs of capital which, in turn, will boost the demand for credit, investment and private consumption, and ultimately growth. This higher growth raises the prospects for future profit and dividend income for both firms and households, which then lifts asset prices and raises the net worth of both households and firms. This higher net worth then feeds back into a reduction in the external finance premium. This financial accelerator mechanism has the potential to result in a credit-asset price cycle that also feeds into a broader macroeconomic cycle in output, consumption, employment, and consumer price inflation. $^{2}$

Macroeconomic effects and, in particular, goods price inflation could, however, take longer to emerge than asset price increases especially in cases where there is a large output gap (that is output below potential) or when inflation expectations are stable and firmly anchored by a credible monetary framework. ${ }^{3}$

In Hong Kong SAR, the risks of this credit asset price cycle is heightened by the potential asynchronous cycles in China and the United States economic cycles and the very different situations in the health of their financial systems. As a result, a protracted accommodative U.S. monetary policy combined with a more rapid return to growth in Hong Kong SAR and the Mainland raises the potential for such cycle to take hold.

\section{A Simulation Of Hong Kong SAR Asset And GoOds Markets When CONFRONTED BY AN ACCOMMOdATIVE U.S. MONETARY STANCE}

This section illustrates through model simulations the effects on the Hong Kong economy from accommodative monetary policy in the United States and a divergence in the cyclical conditions in the U.S., Hong Kong SAR, and the Mainland. The paper uses an expanded version of the IMF Global Integrated Monetary and Fiscal model that incorporates a financial accelerator mechanism and includes 11 Asian economies combined into 5 regions (AustraliaNew Zealand, China, EMEAP6 (Hong Kong SAR, Indonesia, Malaysia, Philippines, Singapore, and Thailand), Japan, and South Korea), 2 advanced economies outside Asia (United States and the euro area), and the rest of the world. ${ }^{4}$

\section{A. Model Overview}

Details of the model's equations are available in Kumhof and Laxton (2009), but we provide a brief summary of the main features.

\footnotetext{
${ }^{2}$ See Bernanke, Gertler, and Gilchrist (1999).

${ }^{3}$ See Borio and Lowe (2002).

${ }^{4}$ See Kumhof and Laxton (2007) and Kumhof et al. (2009).
} 
The model includes unions, manufacturers, capital, investment and consumption goods producers, distributors, households, the government, and banks. Each economy is populated with two types of households, overlapping generations households and liquidity constrained households. The main difference between these two types of households is that the latter do not have access to financial markets, and hence are unable to consume more than their aftertax income each period. Both types of households consume retailed outputs and supply labor to unions. Households with access to financial markets hold domestic currency denominated bonds issued by their government or banks, and foreign currency denominated bonds.

\section{Labor Market}

There is a wide variety of labor supplied by unions. Unions buy labor services from households and sell them to manufacturers at a premium. Imperfect substitutability between the varieties of labor provides the unions with market power over manufacturing firms. Unions face nominal rigidities in their price setting behavior.

\section{Goods Market and Trade}

The production of final consumption and investment goods starts with manufacturers producing tradables and nontradable goods using physical capital rented from entrepreneurs, labor from unions, and energy from global market. The manufacturing goods are then sold to domestic distributors and import agents who operate in foreign economies - this is the first layer of multilateral trade (intermediary goods). Distributors combine domestic and foreignproduced tradable goods with public infrastructure to produce an output that will be used in the production of domestic consumption and investment goods, and will be exported abroad - this is the second layer of multilateral trade (final goods). Investment goods producers sell their final composite to entrepreneurs and the government; consumption goods producers sell their final composite to the government; and retailers sell their output to households.

Manufacturers, and distributors face nominal rigidity in price setting, while retailers and importers are subject to real rigidities since it is costly to rapidly adjust their sales volume. Manufacturers are also subject to real rigidities in capital accumulation. ${ }^{5}$ The model's wide range of rigidities in labor and product markets imply that prices are higher than they would be under a more competitive environment (prices are set as a markup over marginal costs in these markets).

\section{Entrepreneurs and Banks}

Entrepreneurs purchase a capital stock from capital producers, who are subject to investment adjustment costs, and they then rent this capital to manufacturers. Entrepreneurs finance their capital holdings using a combination of external and internal financing - that is with loans

\footnotetext{
${ }^{5}$ For more details, see N'Diaye, Zhang and Zhang (2009).
} 
from banks and their own cash flow. They are subject to a capital income tax, face idiosyncratic shocks that affect the value of their capital at each period, and decide of the level of capital utilization. Entrepreneurs that encounter adverse shocks can have the value of their capital fall beyond a certain level, finding themselves unable to service the loans that they contracted to buy the capital. Those entrepreneurs are considered bankrupt. In such a case, banks recover only a proportion of the value of their assets, with a recovery rate that is stochastic.

Capital producers produce the capital stock that entrepreneurs rent to manufacturers in the non tradable and tradable sectors. Capital producers pay dividends to households in the form of lump sum transfers from their profits. To produce the capital stock these capital producers buy previously installed capital from entrepreneurs and increment it by the flow increase in the capital stock provided by investment goods producers. The previously installed capital stock that they use each period depends on the capacity utilization rate that entrepreneurs have chosen to employ.

\section{Financial Sector}

Banks lend funds to entrepreneurs by borrowing from households (through deposits) and charging entrepreneurs a premium - the external finance premium - depending on their riskiness and the perceived state of the economy. A lower external finance premium reduces the cost of capital and, thus, increases the demand for loans from banks. The total amount of capital that is purchased by entrepreneurs increases leading to higher profits and more dividends paid to households. This, in turn, raises private consumption. At the same time, the higher capital utilization rate, the lower cost of financing, and the increased net worth of the entrepreneurs feeds through into higher aggregate investment. The higher path for output, net worth, and asset prices further lowers the external finance premium creating a feedback process to increased credit growth, higher asset prices and faster output. This is at the core of the financial accelerator mechanism in this modeling framework.

\section{Monetary Policy}

Monetary policy is characterized in two ways: either there is a clear commitment to stabilizing output growth and inflation under a flexible exchange rate regime (employing a Taylor rule approach to setting short-term interest rates. Or the monetary authority maintains a managed float exchange rate regime whereby smoothing exchange rate fluctuations becomes an additional objective of monetary policy. At the extreme under a fixed rate regime, such a monetary policy can be directed at stabilizing the exchange rate (as in the case of Hong Kong SAR). Monetary policy has real effects in this model because of the layers of nominal rigidities that are assumed. These nominal rigidities are compounded by real rigidities in labor hiring, capital investment, imports of investment and consumption goods, distribution, and retail sales.

\section{Fiscal Policy}

Fiscal policy matters both in the short term and in the longer term in the GIMF because the model has four key assumptions that imply non-Ricardian features: (i) households have finite 
economic lifetime which makes them incorporate in their spending decisions only the effects of fiscal policies that are likely to occur during their lifetime; (ii) some of the households are liquidity constrained and are forced to consume all their after-tax income every period; (iii) households' labor productivity declines with age, which implies a higher discount rate for future labor income tax than otherwise; and (iv) labor and consumption taxes are distortionary because they affect labor effort and spending behavior. Fiscal policy aims at stabilizing the debt-to-GDP ratio over the long term by controlling spending or levying taxes. Public spending on investment is productive, providing longer-term output benefits. Governments levy lump-sum taxes, a consumption tax, a labor income tax, and a capital income tax.

\section{B. Model Simulations}

\section{Calibration}

The model has been calibrated building on the work done in conjunction with HKMA staff. ${ }^{6}$ For the financial variables, the initial steady states are set with leverage ratios and borrower's riskiness (probability that an entrepreneur falls into bankruptcy) equal to 2 percent on average across firms. ${ }^{7}$ In terms of the monetary framework, it is assumed that emerging Asian countries block peg their currencies to the U.S. dollar, while all other regions follow a floating exchange rate regime. For economies where the exchange rate is allowed to float, monetary policy aims at stabilizing output and inflation.

\section{Scenario}

The simulations envisage that activity in the United States economy remains weak with a persistent decline in private investment. At the same time, U.S. consumers attempt to restore the health of their balance sheets by increasing their savings rate for an extended period. This weakness in domestic demand implies a lowering of u.s. interest rates relative to where they would be otherwise, with nominal interest rates at about 100 basis points below baseline after two years and 20 basis points after 7 years. We also assume a temporary shift in preferences for domestically produced goods, reducing the relative share of imported goods.

At the same time, it is assumed that Mainland China implements a fiscal stimulus package over two years amounting to $4 \frac{1}{2}$ percent of GDP (3 $1 \frac{1}{2}$ percent of GDP in the first year and 1 percent of GDP in the second year). The fiscal stimulus includes a $2 \frac{1}{2}$ percent of GDP rise in government investment in the first year and $1 / 2$ percent of GDP in the second year, and a reduction in the consumption tax of 1 percent of GDP in the first year and $1 / 2$ percent of GDP in the second year.

\footnotetext{
${ }^{6}$ See N'Diaye, Zhang, and Zhang (2009) for more details.

${ }^{7}$ This is broadly consistent with the level of expected default frequency calculated by Moody's KMV for Hong Kong SAR as at early September.
} 
For Hong Kong SAR, as part of the EMEAP6 group, it is assumed that financial conditions ease temporarily relative to the United States as the monetary transmission reasserts itself. ${ }^{8}$ This leads to a reduction in the external finance premium. It is assumed that the decline in borrowers' riskiness and bankruptcy costs reduce the external finance premium by about 120 basis points relative to the baseline (roughly consistent with a decline in bank spreads to their mid-2006 levels).

\section{Simulation Results}

Under such scenario, output in Hong Kong SAR rises above the baseline as stronger demand for exports to the Mainland and easy financial conditions spur investment, profits, and private consumption. A rise in exports is supported by a real depreciation. However, this is more than offset (at least initially) by a strengthening in imports which lowers the trade balance.

The improved prospects in Hong Kong SAR raise consumption. Household spending increases on the back of higher demand for labor, higher wages, and increased capital income in the form of dividends. However, this is somewhat tempered by the negative effect of lower global interest rates on households income from their foreign asset holdings.

There is more investment as well. This is due to easier financing conditions, the decline in the external finance premium, and an increased demand for credit. At the same time, improved opportunities for profits raises the net worth of both the entrepreneurs and the capital producers.

The exchange rate depreciates in real effective terms as the weak demand and
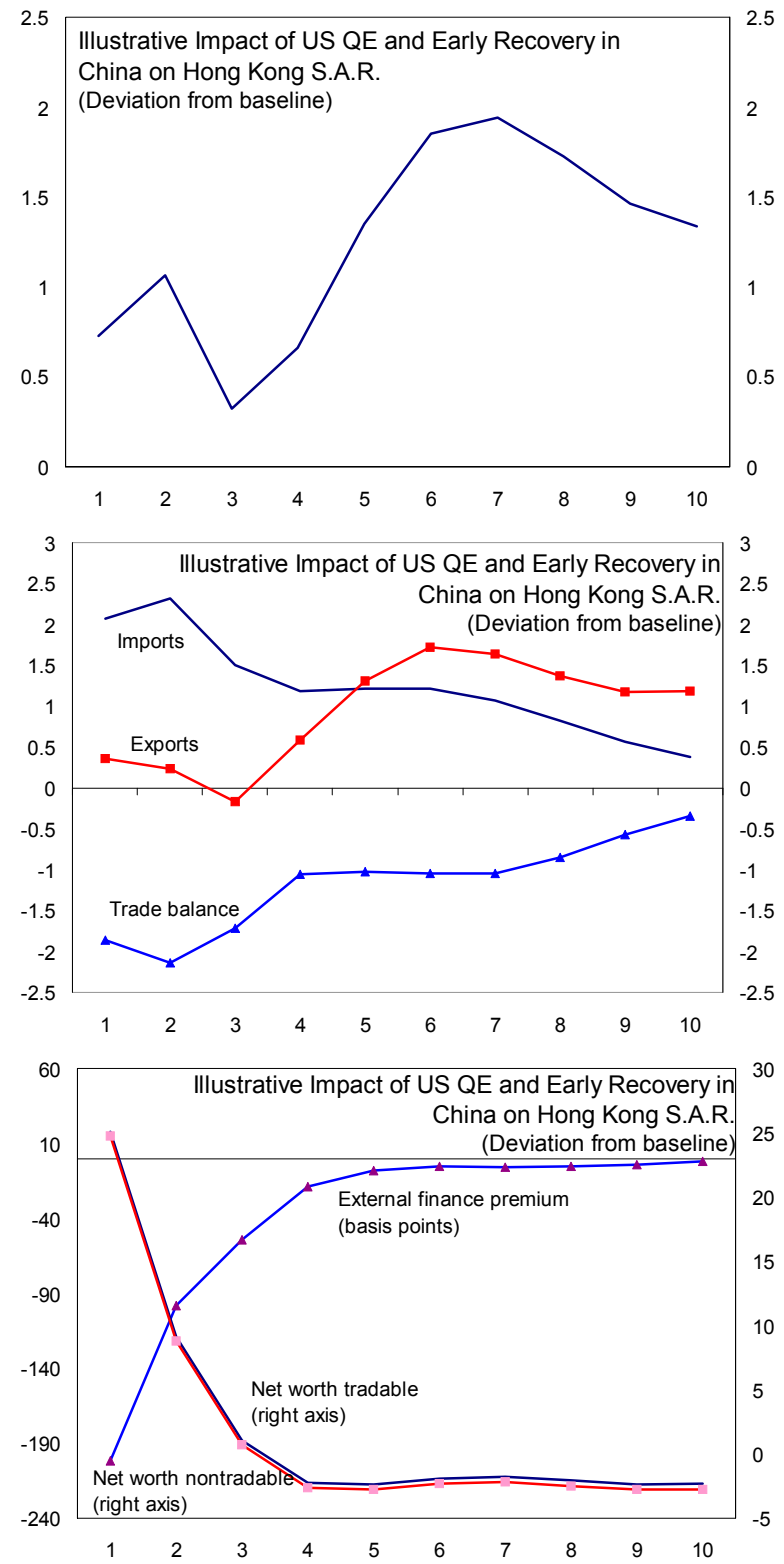

${ }^{8}$ The small size of Hong Kong SAR relative to other blocks prevents us from considering it alone as a separate block in the model. While this treatment may understate somewhat the strong trade linkages between Hong Kong SAR and the Mainland China (which are stronger than the trade linkages between the other economies in the EMEAP6 block and Mainland China), the assumption will not change qualitatively the results given the the nature of the shocks considered here and the composition of the stimulus in China (which is mostly made of public infrastructure spending). 
lower interest rates in the United States leads to a weakening in the U.S. dollar against major currencies (which the Hong Kong dollar follows due to the nature of the exchange rate system).

CPI inflation is higher but the overall impact is somewhat limited. With demand reacting faster than supply initially because of adjustment costs, CPI inflation rises moderately but as increased supply catches

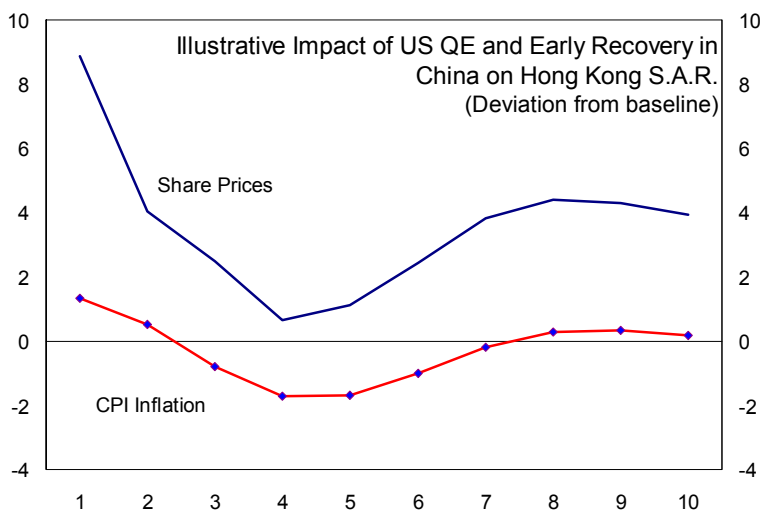
up the pressure for goods prices to rise fades. The inflationary pressure on goods prices is likely to be even more subdued than shown in the model simulation as a result of the current cyclical conditions in Hong Kong SAR. In particular, the large open output gap will reduce inflationary pressures and there will be little pressures for prices and wages to increase to appreciate the real exchange rate.

Asset prices, however, rise much faster than goods prices, spurred by stronger activity and easy financial conditions, and catalyzed by the feedback loop between real and financial variables. Easier financing conditions and improved growth prospects increase profits, investment, private consumption, and ultimately raise output. Firms' net worth increases and asset prices rise. In turn, the higher net worth lowers the external finance premium and stronger economic activity raises profits and further reduces borrowers' risk profile. As such, the external finance premium falls further supporting an upswing in both activity and asset prices.

\section{The Role of the Financial Accelerator}

The rise in asset prices hinges on the presence of the financial accelerator mechanism in the model and the assumed increase in available collateral, lower external finance premium, and improved situation in financial intermediation. A similar simulation exercise performed using the 8-region version of GIMF but without a financial accelerator does not show any positive impact on asset prices, at least in the early years. Without the financial accelerator mechanism, the adverse impact of slower demand from the United States on Hong Kong SAR tends to dominate the positive spillovers from the Mainland's fiscal stimulus package and output declines, asset prices do not increase, and credit growth remains subdued.
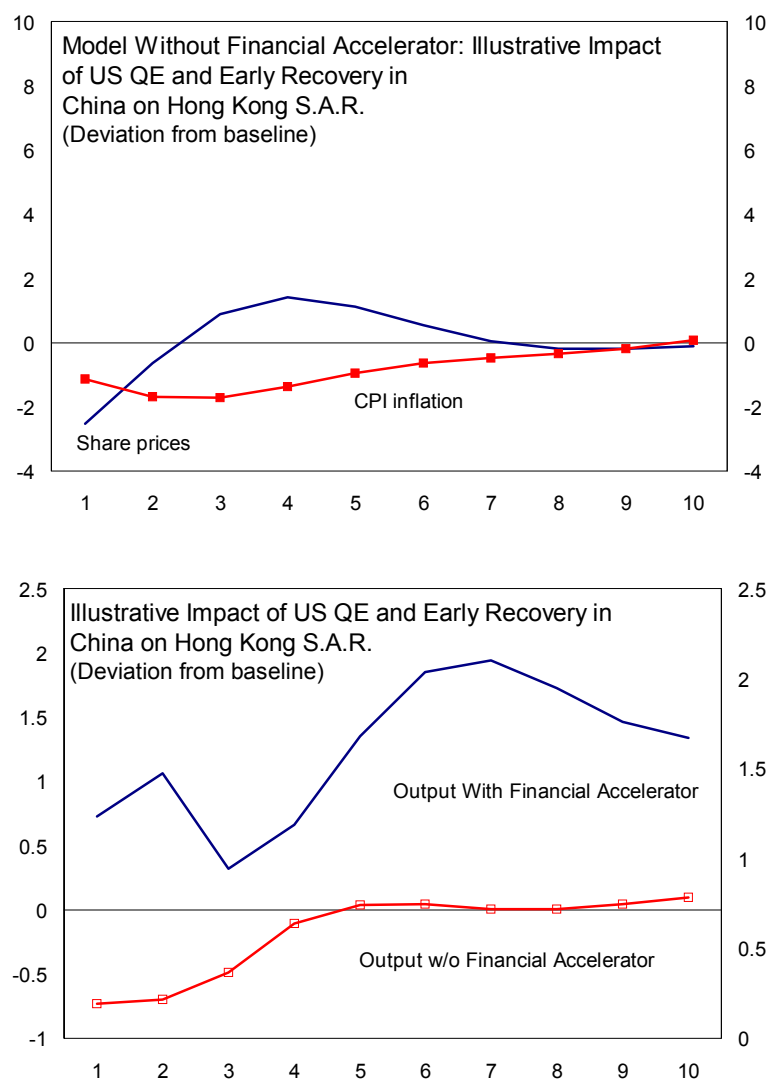
Although, the model does not allow for unstable dynamics, in practice the financial accelerator feedback mechanism could fuel an asset price-credit boom cycle, that may lead to more extreme increases in asset markets and goods markets than seen here. Such a cycle would translate more easily into higher asset than goods prices because of the greater stickiness in the latter. ${ }^{9}$ Such a risk is likely to be higher when interest rates are low relative to output growth (Yanagawa and Grossman 1992) and could be even stronger when it takes time to unwind excess capacity in goods markets. Sustained rapid growth in credit together with higher asset prices increase the likelihood of creating the conditions for financial instability (Borio and Lowe, 2002).

\section{Fiscal Policy}

One could, perhaps, contain the increase in asset prices by taking offsetting action by way of fiscal policy. However, attempting to limit asset price inflation through tighter fiscal policy would require a substantial fiscal contraction. This, in turn, would entail large output losses for the real economy. In particular, model simulations suggest that even a tightening of fiscal policy of 5 percent of GDP would be insufficient to fully counter the rise in asset

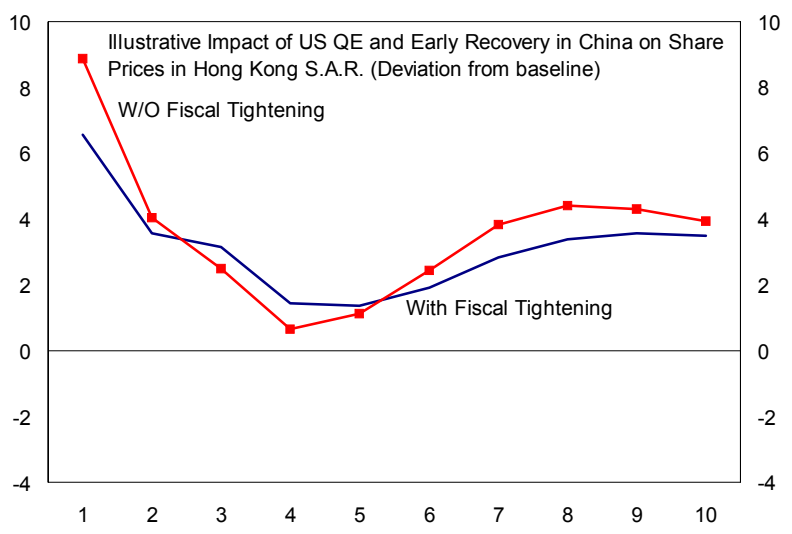
prices but would exert a significant downward draft on the real economy. Moreover, significant lags in the implementation of fiscal policy will likely reduce the effectiveness of such a tool in smoothing asset price movements.

\section{Conclusions}

Given Hong Kong's linked exchange rate system, the outlook for monetary policy in the U.S., and the prospects for growth in both Hong Kong SAR and China, there is a risk of a build up of a credit-asset price cycle in Hong Kong SAR. The evolution of this cycle will depend critically on the resumption of the credit channel in Hong Kong SAR, an increase in the demand for credit, and banks willingness to increase lending. Given the liquidity currently present in the Hong Kong system, there is a potential for a rapid rise in credit growth with consequent implications on asset prices (for both property and equity).

Fiscal policy could restrain this asset price cycle but this would impose quite significant downdraft on the real economy in terms of lower output, consumption and employment. Therefore, there may well be a role for alternative policies - notably changes to prudential regulations such as through tighter underwriting standards, lower loan-to-value ratios, or

\footnotetext{
${ }^{9}$ Borio and Filardo (2003) note the "paradox of credibility" as credibility can on one hand help maintain stable inflation, and on the other hand make it harder for unsustainable booms to translate into overt inflation.
} 
countercyclical capital adequacy requirements - to mitigate the upswing in asset prices and strengthen the financial system's ability to withstand the subsequent unwinding of the cycle. 


\section{References}

Bernanke, B., M. Gertler, and S. Gilchrist, 1999, "The Financial Accelerator in a Quantitative Business Cycle Framework," in Handbook of Macroeconomics, ed. by J. Taylor and M. Woodford (Amsterdam: Elsevier).

Borio , Claudio, and Andrew Filardo, 2003, “A Tale of Two Perspectives: Old or New Challenges For Monetary Policy?” BIS Working Paper No. 127 (Basel: Bank for International Settlements).

Borio, Claudio, and Philip Lowe, 2002, "Asset Prices, Financial and Monetary Stability: Exploring the Nexus,” BIS Working Paper No. 114 (Basel: Bank for International Settlements).

International Monetary Fund, 2009, Global Financial Stability Report, October 2009: Navigating the Financial Challenges Ahead, World Economic and Financial Surveys (Washington).

Kumhof, M., D. Laxton, D. Muir, and S. Mursula, 2009, “The Global Integrated Monetary and Fiscal Model: Theoretical Structure," IMF Working Paper (forthcoming).

N'Diaye, P. M'B. P., P. Zhang, and W. Zhang, 2009, "Structural Reform, Intra-Regional Trade, and Medium-Term Growth Prospects of East Asia and the Pacific-Perspectives From a New Multi-Region Model," Journal of Asian Economics.

Yanagawa N., and G. M. Grossman, 1992, “Asset Bubbles and Endogenous Growth”, NBER Working Paper No. 4004 (Cambridge, Massachusetts: National Bureau of Economic Research). 